
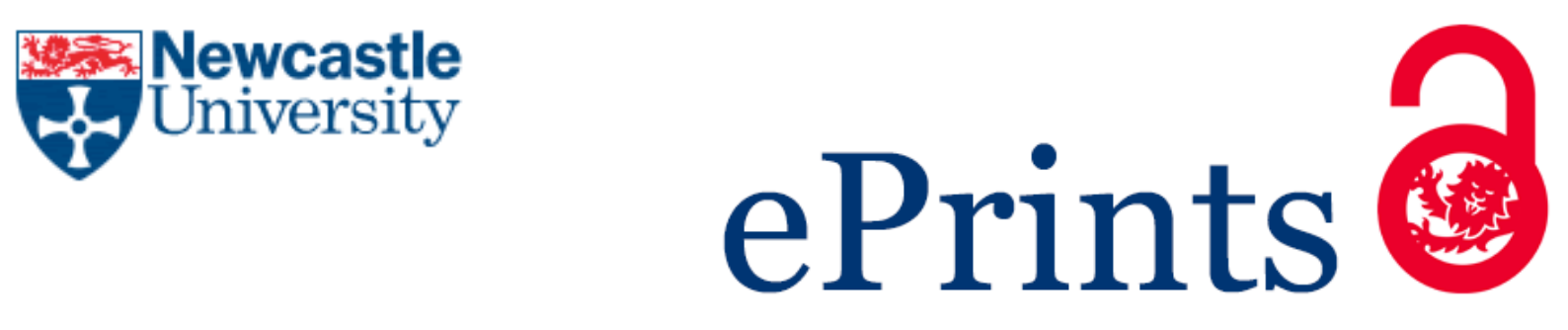

Rozado-Aguirre Z, Adams I, Collins L, Fox A, Dickinson M, Boonham N. Detection and transmission of Carrot torrado virus, a novel putative member of the Torradovirus genus. Journal of Virological Methods 2016, 235, 119-124.

\title{
Copyright:
}

(C) 2016. This manuscript version is made available under the CC-BY-NC-ND 4.0 license

DOI link to article:

https://doi.org/10.1016/j.jviromet.2016.05.018

Date deposited:

$03 / 08 / 2017$

Embargo release date:

01 June 2017

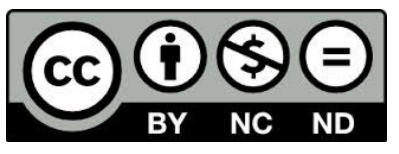

This work is licensed under a

Creative Commons Attribution-NonCommercial-NoDerivatives 4.0 International licence 


\section{Detection and transmission of Carrot torrado virus, a novel putative}

\section{2 member of the Torradovirus genus}

3 Zuriñe Rozado-Aguirre ${ }^{1,2}$, Ian Adams ${ }^{1}$, Larissa Collins ${ }^{1}$, Adrian Fox ${ }^{1}$, Matthew Dickinson ${ }^{2}$, and Neil

4 Boonham $^{1}$

$5 \quad{ }^{1}$ Plant Protection Programme, Fera, Sand Hutton, York, UK, YO41 1LZ

6 'University of Nottingham, Sutton Bonington, Leicestershire, LE12 5RD, United Kingdom

7

*Corresponding author: Tel: +44 0190446 2747; E-mail: zurine.rozado@fera.co.uk

Fera, Sand Hutton, York, YO41 1LZ, United Kingdom.

Keywords: torradovirus, virus, carrots, RT-PCR, RT-qPCR.

Abstract

A new Torradovirus tentatively named Carrot torrado virus (CaTV) was an incidental finding following a next generation sequencing study investigating internal vascular necrosis in carrot. The closest related viruses are Lettuce necrotic leaf curl virus (LNLCV) found in the Netherlands in 2011 and Motherwort yellow mottle virus (MYMoV) found in Korea in 2014. Primers for reverse transcriptasePCR (RT-PCR) and RT-qPCR were designed with the aim of testing for the presence of virus in plant samples collected from the field. Both methods successfully amplified the target from infected samples but not from healthy control samples. The specificity of the CaTV assay was also checked against other known carrot viruses and no cross-reaction was seen. A comparative study between methods showed RT-qPCR was the most reliable method, giving positive results in samples where RT-PCR fails. Evaluation of the Ct values following RT-qPCR and a direct comparison demonstrated this was due to improved sensitivity. The previous published Torradovirus genus specific RT-PCR 
primers were tested and shown to detect CaTV. Also, virus transmission experiments carried out suggest that unlike other species of the same genus, Carrot torrado virus could be aphid-transmitted.

1. Introduction

The genus Torradovirus, within the family Secoviridae was first described to place two new viruses, Tomato torrado virus (ToTV) and Tomato marchitez virus (ToMarV) (Sanfaçon et al., 2009, Verbeek et al., 2007, Verbeek et al., 2008). More recently, new species have also been proposed as members of the genus: Tomato chocolàte virus (ToChV), Tomato chocolàte spot virus (ToChsV), Lettuce necrotic leaf curl virus (LNLCV), Motherwort yellow mottle virus (MYMoV) and Cassava torrado-like virus (CsTLV) (Verbeek et al., 2010, Batuman et al., 2010, Verbeek et al., 2013a, Seo et al., 2014, Carvajal-Yepes et al). ToTV is considered the type species of the genus, it was first found in Spain in 2004 and since then, isolates have been described all around the world (Van der Vlugt et al, 2015). Analysis of its genome structure indicates there are two (+)ssRNA of $\sim 7.7 \mathrm{~kb}(\mathrm{RNA} 1)$ and $\sim 5.2 \mathrm{~kb}$ (RNA2) (Verbeek et al., 2007, Budziszewska et al., 2008). RNA1 contains one open reading frame (ORF) and has coding regions for the protease (Pro), helicase (Hel) and RNA-dependent RNA polymerase (RdRp). RNA2 has two ORFs: The function of ORF1 is still unclear whilst ORF2 encodes three coat proteins (Vp35, Vp26 and Vp23) and the movement protein (MP). Specific primers were designed for the detection of the ToTV (Pospieszny et al., 2007) and two generic primer sets, Torrado-1F/Torrado-1R and Torrado-2F/Torrado-2R, were also designed for the detection and identification of all the other viruses in the genus (Verbeek et al., 2012). Additional sets of primers have been recently developed to detect ToTV isolates from different sources (Herrera et al., 2015). Previous studies showed that torradoviruses are transmitted by the whiteflies Trialeurodes vaporariorum, Trialeurodes abutilonea and Bemisia tabaci, suggesting also that they are transmitted in a semi-persistent and stylet-borne manner (Amari et al., 2008, Barajas-Ortiz et al., 2013, Verbeek et al., 2013b). However, experiments with LNLCV and whiteflies using the same acquisition and inoculation periods did not lead to virus transmission suggesting another vector species could be responsible (Verbeek et al., 2013).

Internal necrosis has been seen in carrots (Daucus carota) in the UK for at least ten years and has been associated with virus infection (Fox, 2011). Recent analysis using next generation sequencing 
53 (NGS), found that Carrot yellow leaf virus (CYLV) was strongly associated with the development of internal necrosis symptoms in carrots (Adams et al., 2014). Several novel viruses were also identified in that study including a new torrado virus tentatively named as Carrot torrado virus (CaTV) (KF533719 and KF533720). Analysis of sequence data showed the closest related virus in the genus

57 Torradovirus was LNLCV (Adams et al., 2014). The acronym CaTV for Carrot torrado virus was later proposed in order to avoid confusion with Carrot tristeza virus (CTV) (van der Vlugt et al., 2015).

This study describes the development of a rapid and reliable molecular detection method for the identification of the first Torradovirus found in carrots, Carrot torrado virus, using reverse-transcriptase (RT)-PCR and RT-qPCR and describes the first report of aphid transmission of one member of the Torradovirus genus.

\subsection{Source of samples}

Carrot leaves exhibiting a range of foliar symptoms (interveinal chlorosis, generalised chlorosis, tip reddening and tip necrosis) and asymptomatic leaves were taken from Elveden Estate Field, Thetford, Norfolk, UK (Latitude 52.3656, Longitude -0.56407). Weed samples from the Apiaceous family, assumed to be more likely infected with carrot viruses, were also taken from the margins of Bratleys Field, Stamford Bridge, Yorkshire, UK (Lat. 53.9992, Long. -0.8855) and Sutton Park field, Sutton on the Forest, Yorkshire, UK (Lat. 54.0577, Long. -1.0518). ToTV infected plants were kindly supplied by the Plant Protection Service in the Netherlands for comparative testing.

\subsection{Nucleic Acid extraction}

Carrot leaves and weed samples were extracted using the Kingfisher ${ }^{\circledR} \mathrm{mL}$ system (Thermo labsystems) following the method described in Mumford et al., 2002 and 2003. Leaf material was 
ground in lysis buffer and centrifuged at $13000 \mathrm{rpm}$ for $1 \mathrm{~min}$. Samples were then loaded into the instrument and the extraction protocol was followed as described. RNA was eluted in $200 \mu \mathrm{l}$ of molecular grade water and stored at $-20^{\circ} \mathrm{C}$.

\subsection{Conventional RT-PCR assay setup}

Two pairs of CaTV primers were designed using Primer Express 2 (Applied Biosystems) for a RTPCR assay according to the sequencing data obtained by Adams et al., (2014) (table 1). The primers designed to RNA1 amplify a fragment of $262 \mathrm{bp}$ and RNA2 primers a fragment of $299 \mathrm{bp}$. The extracted sample $(1 \mu \mathrm{l})$ was added to a $24 \mu \mathrm{l}$ reaction mix, containing Verso ${ }^{\mathrm{TM}}$ 1-Step RT-PCR ReddyMix $^{\mathrm{TM}}$ Kit (Thermo Scientific) and $400 \mathrm{mM}$ of each primer. Assays were carried out in a Bio-Rad $\mathrm{C} 1000^{\mathrm{TM}}$ thermal cycler (Bio-Rad laboratories) and PCR conditions consisted of $45 \mathrm{~min}$ at $48{ }^{\circ} \mathrm{C}$ for cDNA synthesis, 2 min at $94^{\circ} \mathrm{C}$, then 40 cycles of, $30 \mathrm{sec}$ at $94^{\circ} \mathrm{C}, 1$ min at $56^{\circ} \mathrm{C}$ and $1 \mathrm{~min}$ at $68^{\circ} \mathrm{C}$ and a final extension step for 6 min at $68^{\circ} \mathrm{C}$. These conditions followed the method described in Verbeek et al. 2012, but primer annealing temperature of $56^{\circ} \mathrm{C}$ was chosen for CaTV when a gradient primer annealing temperature test was performed on a CFX96 Touch Thermal cycler (BioRad laboratories) for optimization. PCR products were separated using a $1.8 \%$ agarose gel (130 V) stained with ethidium bromide, visualized in a UV transilluminator. Products were purified using the QIAquick ${ }^{\circledR}$ PCR Purification kit (Qiagen) before being sent for sequencing. Generic Torradovirus genus assays were performed following the method described in Verbeek et al., (2012).

Primers and probes for the real-time assay were designed using Primer Express 2 (table 1). The 5'and 3'- ends of the probes were labelled with the reporter dye FAM (6-carboxyfluorescein) and quencher dye TAMRA (tetra-methylcarboxyrhodamin). A concentration of $300 \mathrm{nM}$ of each primer and $100 \mathrm{nM}$ of probe were used in each $25 \mu$ reaction and same conditions were used for both RNAs. 
Reactions were carried out in 96 well plates using the ABI 7900 (Applied Biosystems). Positive controls consisting of a CaTV sample obtained by NGS and negative controls consisting of healthy leaf material and water were used to validate the results. RT-qPCR cycling conditions were: $10 \mathrm{~min}$ at $55^{\circ} \mathrm{C}$ for the reverse transcription followed by $8 \mathrm{~min}$ at $95^{\circ} \mathrm{C}$ and then 40 cycles of $10 \mathrm{sec}$ at $95^{\circ} \mathrm{C}$ and $1 \mathrm{~min}$ at $60^{\circ} \mathrm{C}$. Results were analysed using the SDS 2.4 Software (Applied Biosystems). A threshold cycle (Ct) value below 40 was considered as a positive result and was fixed by default parameters of the Software.

\subsubsection{Validation experiments}

The efficiency of the new assays for both RNAs was measured using serial 10-fold dilutions (from 1 to $10^{-8}$ ) of total RNA from plant infected extracts quantified using the Nanodrop ND-1000 Spectrophotometer (Labtech). Samples were chosen from a pool of positive samples previously tested using RT-qPCR and all the dilutions were tested in duplicate in the same run. Standard curves were generated using the Ct values obtained and the logarithm of the dilution and regression coefficient represented. Specificity of the real-time test was assessed using a panel of carrot and other viruses. Analytical sensitivity was also compared to a RT-PCR assay comparing RT-qPCR Ct values with band intensity of the PCR product after gel electrophoresis.

\subsection{Transmission experiments}

Infected leaves were ground in potassium phosphate buffer, $\mathrm{pH}$ 7.7., mixed with cellite and inoculated onto leaves of ten plants of Nicotiana benthamiana, Anthriscus cerefolium (chervil) and Daucus carota (carrot). Plants were kept in the green house with a 12 hours photoperiod and an average temperature between $18-20^{\circ} \mathrm{C}$. Five mock inoculated plants of each species were also used as controls and kept in the same conditions. All plants were assessed weekly for symptom development and tested for virus presence using RT-qPCR from random leaves. 
supplemental lighting). Aphids were then used to inoculate $3 \times 50$ trays of healthy cotyledon stage N.benthamiana, chervil and carrots. Healthy plants of each species were also used as negative controls. Each aphid was transferred onto an individual indicator plant and covered with a plastic tube (30 mm dia. $\times 110 \mathrm{~mm})$ to prevent it from escaping. The tubes were removed after $24 \mathrm{~h}$ and the aphids killed by spraying the plants with Bug Clear Ultra (0.05gl-1 acetamiprid, The Scotts Company (UK) Ltd), following the manufacturer's instructions. The plants were grown on in a plant growth room (20 ${ }^{\circ} \mathrm{C}, 60 \% \mathrm{RH}, \mathrm{L} 16 \mathrm{~h}: \mathrm{D}$ 8h) for three weeks when they were tested for virus presence using RT-qPCR.

3. Results

\subsection{Diagnostic performance of RT-PCR}

Comparison of primer sequences to sequences in Genbank using BLAST did not indicate significant homology with any other species except the targets. Assays for RNA1 and RNA2 were evaluated using extracts of carrot leaf samples from the field. Amplification products were analysed using agarose gel electrophoresis and results showed a single amplicon of the desired size for both primer sets, 262 bp for RNA1 and 299 bp for RNA2 (figure 1a). RT-PCR products were purified and sequenced confirming CaTV virus presence. No PCR products were amplified from the healthy or water controls and primer pairs did not produce non-specific amplicons.

Specific Torradovirus genus primers developed by Verbeek et al., (2012) were evaluated for the detection of CaTV and compared with the species specific assays. As expected the Generic set of primers detected an amplicon of $514 \mathrm{bp}$ from CaTV and 515 from ToTV (figure 1b). The CaTV assay developed did not cross react with ToTV, similarly, the ToTV assay did not amplify CaTV.

Comparative analysis of the sequences using MEGA 6 did not indicate cross-reaction with LNLCV or MYMoV, non-tomato Torradoviruses and the closest related viruses to CaTV.

\subsection{Detection of CaTV by RT-qPCR}


Each primer sequence was compared to published sequence information available and no crossreaction was found (NCBI, BLAST). The RT-qPCR assay was evaluated using samples collected from the field on an ABI $7900 \mathrm{HT}$ system (Applied Biosystems). Amplification curves gave Ct values between 15.98 and 33.19 for RNA1 and 17.02 and 32.69 for RNA2, indicating virus presence in the samples. A test designed to detect the cytochrome oxidase gene sequence (COX) of the plant was also used as an internal control. Detection of one of the two RNAs was considered as a positive result. Negative controls consisting of RNA extracts from healthy plants extracts and water were used and no amplification was detected.

To test the specificity of the assays, a range of UK field isolates affecting carrots, related and unrelated viruses were used: ToTV (Tomato torrado virus), CYLV (Carrot yellow leaf virus), CRLV (Carrot red leaf virus), CRLaV (Carrot red leaf associated virus), CMoV (Carrot Mottle virus), CtCV1 (Carrot closterovirus 1), PYFV (Parsnip yellow fleck virus), CMV (Cucumber mosaic virus), SLRV (Strawberry latent ringspot virus), TBRV (Tomato black ring virus) and PVY (Potato virus Y). Each assay was run in triplicate for every virus and no amplification was found between the species tested or the healthy or negative controls for RNA1 and RNA2 (table 2). For RNA1, a Ct value of 38.12 and 39.9 was obtained for CYLV and CMoV respectively in one of the replicates. Those samples were tested again and no amplification was seen.

In order to assess the efficiency of the assays, standard curves for RNA1 and RNA2 were generated with 10-fold serial dilutions of total RNA (plant + virus) from a pool of positive samples to determine the maximum dilution detected. For each dilution, two replicates with $1 \mu$ l of total RNA were prepared in a $25 \mu \mathrm{l}$ well. Results showed standard curves with 0.9932 and 0.9956 regression coefficients $\left(R^{2}\right)$ for RNA1 and RNA2 respectively (figure 2a). Both assays were assessed following the guideline described in OEPP/EPPO Bulletin PM7/98 (2), 2014, (table 3). Repeatability tests were

187 performed for both RNAs with the lowest level of dilution detected reliably in the sensitivity assays and six replicates of each sample were tested. Ct values between 33.91 and 35.17 were obtained with a standard deviation (SD) of \pm 0.46 for RNA1 and between 32.15 and 32.63 with a SD of \pm 0.19 for 
RNA2 were obtained. No differences were seen either when tested by two different operators in two different 7900 HT systems.

Diagnostic sensitivity of the RT-qPCR assay was also compared to RT-PCR. Results showed that the developed RT-qPCR was more sensitive than the conventional method detecting dilutions ranging between $19 \mathrm{ng}$ and $1.9 \mathrm{pg}$ and detecting levels of dilution up to $10^{-5}$ for RNA1 and $10^{-4}$ for RNA2 (figure 2b), 1000 and $10^{4}$ times more sensitive than the conventional method which detected levels of dilution of $10^{-1}$ in both RNAs (figure $2 \mathrm{c}$ ). Further comparisons were made between both methods using a pool of 45 samples collected from the field. For RNA1, RT-qPCR detected 23 positive samples $(51.1 \%)$ while RT-PCR detected virus presence in a total of 20 samples (44.4\%) (data not shown). When tested for RNA2, RT-PCR gave positive results in 27 of the samples (60\%) in comparison with the 31 positives obtained by RT-qPCR (68.8\%) (figure $2 \mathrm{~d}$ ).

3.4. CaTV transmissionMechanical transmission experiments with $N$. benthamiana, chervil and carrots resulted in one symptomless $N$. benthamiana CaTV infected plant. Weed samples surrounding carrot fields consisting of 30 cow parsley (Anthriscus sylvestris), and 19 hogweed (Heracleum sphondylium), were collected and tested to look for possible sources of CaTV infection in carrots but all tested negative for the virus (data not shown). Aphid transmission experiments with $M$. persicae and $C$. aegopodii resulted in some symptomatic chervil and $N$ benthamiana plants when tested by RT-qPCR. Transmission rates of $35.3 \%$ and $12.7 \%$ were found in chervil and tobacco plants respectively with $M$. persicae . Lower transmission rates were achieved when using C.aegopodii in both plant species (table 4). Carrot to carrot transmission of $10 \%$ and $2.7 \%$ was also seen with $M$. persicae and $C$. aegopodii respectively. Virus was successfully transmitted from infected Chervil to healthy carrots using M. persicae and $2 \%$ of the plants tested positive for the virus. All the negative controls consisting of healthy carrot, N. benthamiana and chervil plants were also used for each experiment and tested negative for CaTV.

\section{Discussion}

CaTV was firstly detected in the UK in 2013 in a study investigating the agent responsible of the development of necrotic symptoms in carrots (Adams et al., 2014). In order to detect CaTV infected 
plants from the field and study its transmission, RT-PCR and RT-qPCR assays were developed and optimized. Both methods are routinely used in diagnostic laboratories for the detection of pathogens. In this study both methods successfully amplified CaTV RNA1 and RNA2 in infected samples collected from the field. Neither assay cross-reacted with ToTV, the first Torradovirus found and type member of the genus, indicating the specificity of the assays. Several studies had been performed previously using RT-PCR and two generic primer sets were developed for the detection of all the viruses of the Torradovirus genus (Verbeek et al., 2012). These sets of primers were evaluated and the detection of CaTV RNA1 and CaTV RNA2 using the same cycling conditions was confirmed. Assays were subjected to the EPPO validation international standard method and all the requirements were met. Validation experiments using RT-qPCR were carried out and it was seen to detect virus levels up to $1.9 \mathrm{pg}$. In specificity assays, samples with Ct values between 36 and 40 were re-tested to confirm if there was cross-reaction or low level contamination due to late amplification of some random samples. Re-testing confirmed there was no cross-reaction with any of the species tested. Similar results were obtained when the assays were performed by different people, different days in different $7900 \mathrm{HT}$ systems indicating the reproducibility and repeatability for both RNAs and the robustness of the developed assays. RT-qPCR method gave positive results in field samples where RT-PCR failed and further comparison between both methods indicated this was due to improved sensitivity.

Some samples were found to be only positives for RNA1 but negative for RNA2 and vice-versa when tested using RT-PCR or RT-qPCR, describing possible replication differences between RNAs when infection takes place in the host. The performance of the tests for both RNAs is recommended to avoid any false negative result.

240 CaTV was successfully inoculated and transmitted to healthy $N$. benthamiana and Chervil plants but symptom description was not possible due to infection with Carrot red leaf virus too. Previously studies suggested that tomato infecting Torradoviruses were transmitted by different whiteflies species (Amari et al., 2008, Verbeek et al., 2013b). However, aphid transmission experiments developed in the glasshouse with CaTV, indicated that $M$. persicae could be the natural vector of the virus to carrots. Equally, LNLCV did not result in transmission when experiments with whiteflies were carried out suggesting there could be another different species involved (Verbeek et al., 2013). These 
results might conclude the possibility that non-tomato infecting Torradoviruses could be transmitted by different species than tomato infecting Torradoviruses. Back transmission experiments also showed the virus can be transmitted between members of the Apiaceae family. Additional studies are currently being carried out with $M$. persicae in order to establish virus acquisition and virus inoculation periods.

In 2008, ToTV was found in weed species from Amaranthaceae, Caryophyllaceae, Chenopodiaceae, Cruciferae, Malvaceae, Polygonaceae, and Solanaceae families (Alfaro-Fernandez et al., 2008) indicating they could act as reservoir hosts for this virus before their transmission to tomatoes by aphids. However, limited surveys carried out in 2014 and 2015 with weeds from several species, 59 Hogweed (Heracleum sphondylium), 27 Cow Parsley (Anthriscus sylvestris), one Hemlock (Conium maculatum) and three Rough chervil (Chaerophyllum temulum) did not identify any alternative host for CaTV suggesting that infection could come from another different source. Due to the limited number of weed samples tested, further studies need to be carried out in order to establish possible sources of infection in carrots with CaTV.

The study describes the development of a new, reliable, and sensitive RT-qPCR method for the detection of CaTV and the first report of aphid transmission of a member of the Torradovirus genus. However, additional studies are also currently being carried out evaluating CaTV host range, transmission and further weed testing. Symptom development and incidence of this virus in the UK will also be assessed in order to obtain a complete characterization of this new finding.

This research was supported as project FV 382b through UK government funding under Defra Plant Health Capability. We specially thank the Plant Protection Service from the Netherlands for providing us ToTV positive samples. 
Adams I.P., Skelton, A., Macarthur, R., Hodges, T., Hinds, H., Flint, L., Deb Nath, P., Boonham N., Fox. A., 2014. Carrot yellow leaf virus is associated with Carrot Internal Necrosis. PLOSone 9, Issue $11, \mathrm{e} 109125$.

Alfaro-Fernández, A., Córdoba-Sellés, C., Cebrián, MC., Herrera-Vásquez, JA., Sánchez-Navarro, JA., et al. 2008. First report of Tomato torrado virus on weed hosts in Spain. Plant Dis. 92:831

Amari, K., Gonzalez-Ibeas, D., Gómez, P., Sempere R.N., Sanchez-Pina, M.A., Aranda M.A., 2008. Tomato torrado virus is transmitted by Bemisia tabaci and Infects Pepper and Eggplant in Addition to Tomato. Plant disease 92, 1139.

Barajas-Ortiz, M., León-Sicairos, CR., López-Valenzuela, JA., Reyes-Moreno, C., Valdez Ortiz, A., et al. 2013. Transmission efficiency of Tomato apex necrosis virus by Bemisia tabaci (Hemiptera: Aleyrodidae) biotype B in tomato. J. Econ. Entomol. 106:1559—65

Batuman, O., Kuo, Y.W., Palmieri, M., Rojas, M.R., Gilbertson, R.L., 2010. Tomato chocolàte spot virus, a member of a new torradovirus species that causes a necrosis-associated disease of tomato in Guatemala. Arch. Virol. 155, 857-869.

Budziszewska, M., Obrepalska-Steplowska, A., Wieczorek, P., Pospieszny, H., 2008. The nucleotide sequence of a Polish isolate of Tomato torrado virus. Virus Genes Volume 37, 400-406.

Carvajal-Yepes, M., Olaya, C., Lozano, I., Cuervo, M., Castaño, M., Cuellar, WJ., 2014. Unraveling complex viral infections in cassava (Manihot esculenta Crantz) from Colombia. Virus Res. 186:76--86

Fox, A., 2011. Symptomatic survey of virus complexes of carrot, Final report for project FV382, Horticultural Development Company.

Herrera-Vásquez, JA., Rubio L., Alfaro-Fernandez A, Debreczeni DA., Font-San Ambrosio I, Falk, BW., Ferriol, I., 2015. Detection and absolute quantitation of Tomato torrado virus (ToTV) by real time RT-PCR. J. Virol. Methods, 221 90-94. 
304

305

306

307

308

309

310

311

312

313

314

315

316

317

318

319

320

321

322

323

324

325

326

327

328

329

330

331

Mumford, R.A., 2002. Kingfisher ${ }^{\circledR} \mathrm{mL}$ : a new tool for aiding the detection of plant viruses using realtime PCR. Thermo Labsystems Kingfisher Application Note No. 2. Thermo Labsystems, Vantaa, Finland.

Mumford, R.A., Skelton, A., MetCalfe, E., Walsh, K., Boonham, N., 2004. The reliable detection of Barley yellow and mild mosaic viruses using real-time PCR (TaqMan®). J. Virol. Methods, 117 153159.

PM 7/98 (2) Specific requirements for laboratories preparing accreditation for a plant pest diagnostic activity, 2014. Bulletin OEPP/EPPO Bulletin (2014) 44 (2), 117-147.

Pospieszny, H., Borodynko, N., Obrępalska-Steplowska, A., Hasiow, B., 2007. The first report of Tomato torrado virus in Poland. Plant disease 91, Number 10, p1364.

Sanfaçon, H., Wellink, J., Le Gall, O., Karasev, A., van der Vlugt, R., Wetzel, T., 2009. Secoviridae: a proposed family of plant viruses within the order Picornavirales that combines the families

Sequiviridae and Comoviridae, the unassigned genera Cheravirus and Sadwavirus, and the proposed genus Torradovirus. Archives of Virology, 154, 899-907.

Seo, J.K., Kang, M., Kwak, H.R., Kim M.K., Kim, C.S., Lee, S.H., Kim, J.S., Choi H.S., 2014.

Complete genome sequence of motherwort yellow mottle virus, a novel putative member of the genus Torradovirus. Archives of Virology, 160(2) 587-90.

van der Vlugt, R., Verbeek, M., Dullemans, AM, Wintermantel, WM., Cuellar, WJ., Fox, A., Thompson, JR., 2015. Torradoviruses. Annual Review of Phytopathology, Vol. 53: 485-512

Verbeek, M., Dullemans, A.M., van den Heuvel, J.F.J.M., Maris, P.C., van der Vlugt R., 2007. Identification and characterization of tomato torrado virus, a new plant picorna-like virus from tomato. Archives of Virology, 152 881-890. 
333 Verbeek, M., Dullemans, A.M., van den Heuvel, J.F.J.M., Maris, P.C., van der Vlugt R., 2008. Tomato 334 marchitez virus, a new plant picorna-like virus from tomato related to tomato torrado virus. Archives of 335 Virology, 153 127-134.

336

337 Verbeek, M., Dullemans, A.M., van den Heuvel, J.F.J.M., Maris, P.C., van der Vlugt R., 2010. Tomato 338 chocolàte virus: a new plant virus infecting tomato and a proposed member of the genus

339 Torradovirus. Archives of Virology, 155 751-755.

340

341 Verbeek, M., Tang, J., Ward L.I., 2012. Two generic primer sets for the detection of members of the 342 genus Torradovirus. J. Virol. Methods, 185 184-188.

343

344 Verbeek, M., Dullemans, A., van Raaij, H.M., Verhoeven, J., van der Vlugt, R., 2013. Lettuce necrotic 345 leaf curl virus, a new plant virus infecting lettuce and a proposed member of the genus Torradovirus. 346 Archives of Virology, 159, Issue 4, 801-805.

347

348 Verbeek, P.J., van Bekkum, A.M., Dullemans, A., van der Vlugt, R., 2013. Torradoviruses are 349 transmitted in a semi-persistant and stylet-borne manner by different whitefly vector. Virus Research $350186,55-60$. 


\section{Tables}

\section{Table 1}

354 RT-PCR and RT-qPCR CaTV RNA1 and RNA2 primers used during the study.

\begin{tabular}{|c|c|c|c|}
\hline & Primer & Sequence $\left(5^{\prime}-3^{\prime}\right)$ & Location (nt) \\
\hline \multirow{4}{*}{$\begin{array}{l}\text { 品 } \\
\text { 芒 } \\
\text { r }\end{array}$} & CaTVPCR $1 \mathrm{~F}$ & TCAATCAGTATTAAGCGAGGAATGG & $2742-2762$ \\
\hline & CaTVPCR1R & CCTCAATGGGCTTGTAATGA & $2985-3004$ \\
\hline & CaTVPCR 2F & TGTGCAACCACGAGGAATACA & $3942-3962$ \\
\hline & CaTVPCR 2R & GATGCCTCATAGCAAACTGTCAT & $4219-4241$ \\
\hline \multirow{6}{*}{ 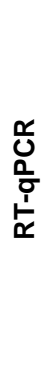 } & CaTV-1F & CCGTTGTTATTCGTCTTCCTCAA & $2819-2841$ \\
\hline & CaTV-1R & TGGATGATTGTAAATACTGCACCAT & $2918-2942$ \\
\hline & CaTV-1P & FAM-TTCAGAGGTGTTTACGTGAGATCGGGATG-TAMRA & \\
\hline & CaTV-2F & TTACAAAGACTACTGGTGATCGTGACTT & $2654-2681$ \\
\hline & CaTV-2R & ATTCGTACAAACCCACCTCAAAG & $2730-2752$ \\
\hline & CaTV-2P & FAM-AGAGTTGGAAATGATGCAACCCATGATAGC-TAMRA & \\
\hline
\end{tabular}

366 
Table 2

CaTV RT-qPCR assay specificity was tested against ToTV, carrot viruses and non-target viruses*.

\begin{tabular}{|c|c|c|c|c|c|c|c|c|c|c|c|c|c|}
\hline & CaTV & ToTV & CYLV & CRLV & CRLaV & CMoV & CtCV1 & PYFV & CMV & SLRV & TBRV & PVY & $\mathrm{HC}$ \\
\hline RNA1 Ct & $15.98 \pm 0.0(3 / 3)$ & - & $38.12(1 / 3)^{\star \star}$ & - & - & $39.9(1 / 3)^{\star *}$ & - & - & - & - & - & - & - \\
\hline RNA2 Ct & $17.47 \pm 0.14(3 / 3)$ & - & - & - & - & - & - & - & - & - & - & - & - \\
\hline
\end{tabular}
*ToTV (Tomato torrado virus), CYLV (Carrot yellow leaf virus), CRLV (Carrot red leaf virus), CRLaV (Carrot red leaf associated virus), CMOV (Carrot Mottle virus), CTCV1 (Carrot closterovirus 1), PYFV (Parsnip yellow fleck virus), CMV (Cucumber mosaic virus), SLRV (Strawberry
latent ringspot virus), TBRV (Tomato black ring virus), PVY (Potato virus Y).

*" Samples tested negative when assay was repeated, indicating there was no cross-reaction with any other viruses. 
Table 3: Validation results obtained for CaTV RNA1 and RNA2 assays following the criteria described in OEPP/EPPO Bulletin PM $7 / 98$ (2).

\begin{tabular}{|c|c|c|}
\hline & CaTV RNA1 & CaTV RNA2 \\
\hline $\begin{array}{l}\text { Sensitivity } \\
\text { Ct value obtained for the smallest amount of target detected reliably }\end{array}$ & $36.48 \pm 0.66$ & $33.6 \pm 1.46$ \\
\hline $\begin{array}{l}\text { Specificity } \\
\text { Cross reacts with }\end{array}$ & - & - \\
\hline $\begin{array}{l}\text { Repeatability } \\
\text { Calculated \% of agreement for a low concentrated sample ( } 10^{-5} \text { dilution) } \\
\mathrm{Ct}\end{array}$ & $\begin{array}{c}100 \% \\
34.33 \pm 0.46 \\
(33.91-35.17)\end{array}$ & $\begin{array}{c}100 \% \\
32.43 \pm 0.19 \\
(32.15-32.63)\end{array}$ \\
\hline $\begin{array}{l}\text { Reproducibility } \\
\text { Calculated \% of agreement for a low concentrated sample }\left(10^{-4} \text { dilution }\right) \\
\text { Operator } 1:\end{array}$ & $100 \%$ & $100 \%$ \\
\hline $\begin{array}{l}7900 \mathrm{HT} \text { system } 1 \mathrm{Ct} \\
7900 \mathrm{HT} \text { system } 2 \mathrm{Ct}\end{array}$ & $\begin{array}{l}34.93 \pm 0.49 \\
34.77 \pm 0.55\end{array}$ & $\begin{array}{l}33.34 \pm 0.23 \\
33.38 \pm 0.83\end{array}$ \\
\hline Operator 2: $\begin{aligned} 7900 \mathrm{HT} \text { system } 1 \mathrm{Ct} \\
7900 \mathrm{HT} \text { system 2 } \mathrm{Ct}\end{aligned}$ & $\begin{array}{l}34.97 \pm 0.44 \\
34.66+0.40\end{array}$ & $\begin{array}{l}31.99 \pm 0.11 \\
31.91+0.27\end{array}$ \\
\hline
\end{tabular}


Table 4

Results of transmission experiments using Cavariella aegopodii and Myzus persicae aphid species from chervil and carrot to three blocks of 50 Nicotiana benthamiana, Chervil and carrot plants.

\begin{tabular}{|c|c|c|c|c|c|}
\hline \multirow[t]{2}{*}{ Source } & \multirow[t]{2}{*}{ Species } & \multicolumn{2}{|c|}{ M. persicae } & \multicolumn{2}{|c|}{ C. aegopodii } \\
\hline & & Positives & $\%$ transmission & Positives & $\%$ transmission \\
\hline \multirow[t]{3}{*}{ Carrot (D. carota) } & N. benthamiana & $\begin{array}{l}10 / 50 \\
2 / 50 \\
7 / 50\end{array}$ & 12.7 & $\begin{array}{l}0 / 0 \\
0 / 0 \\
0 / 0\end{array}$ & 0 \\
\hline & Chervil & $\begin{array}{l}18 / 50 \\
13 / 50 \\
23 / 50\end{array}$ & 35.3 & $\begin{array}{l}3 / 50 \\
0 / 50 \\
4 / 50\end{array}$ & 4.7 \\
\hline & Carrot & $\begin{array}{l}5 / 50 \\
6 / 50 \\
4 / 50\end{array}$ & 10 & $\begin{array}{l}1 / 50 \\
2 / 50 \\
1 / 50\end{array}$ & 2.7 \\
\hline $\begin{array}{c}\text { Chervil ( A.cerefolium) back } \\
\text { transfer }\end{array}$ & Carrot & $\begin{array}{l}1 / 50 \\
2 / 50 \\
0 / 50\end{array}$ & 2 & - & - \\
\hline
\end{tabular}

Page $\mathbf{1 7}$ of $\mathbf{2 1}$ 


\section{Figure legends}

2

3 Figure 1: RT-PCR products for RNA1 (266 bp) and RNA2 (299 bp) using CaTV specific primers (a).

$4 \quad$ CaTV and ToTV gel bands obtained when CaTV, ToTV and Torradovirus genus sets of primers were 5 used (b).

6

7 Figure 2: RT-qPCR standard curves and linear regression coefficients $\left(\mathrm{R}^{2}\right)$ for RNA1 and RNA2 using 8 serial 10-fold dilutions of total RNA with primers described in table 1 (2a). Amplification plots obtained 9 using RT-qPCR (2b). Gel bands obtained with CaTV serial diluted samples using RT-PCR (2c).

10 Comparative test between RT-qPCR and RT-PCR using a pool of 45 samples collected from the field 11 (figure 2d). 
Figure 1
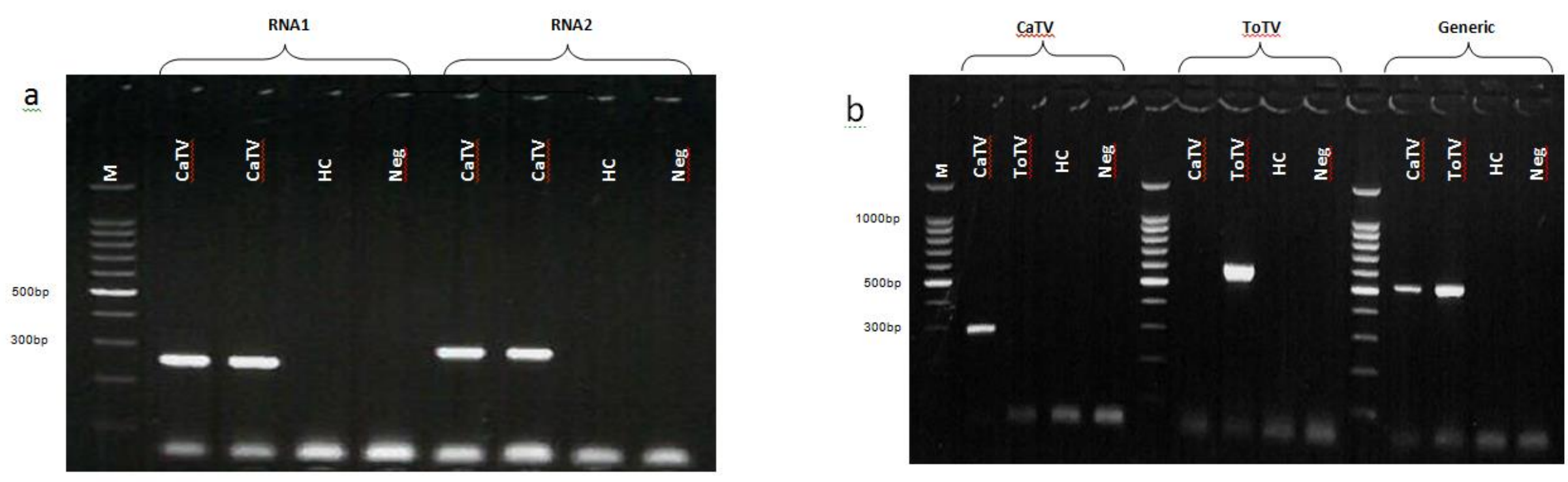
Figure 2
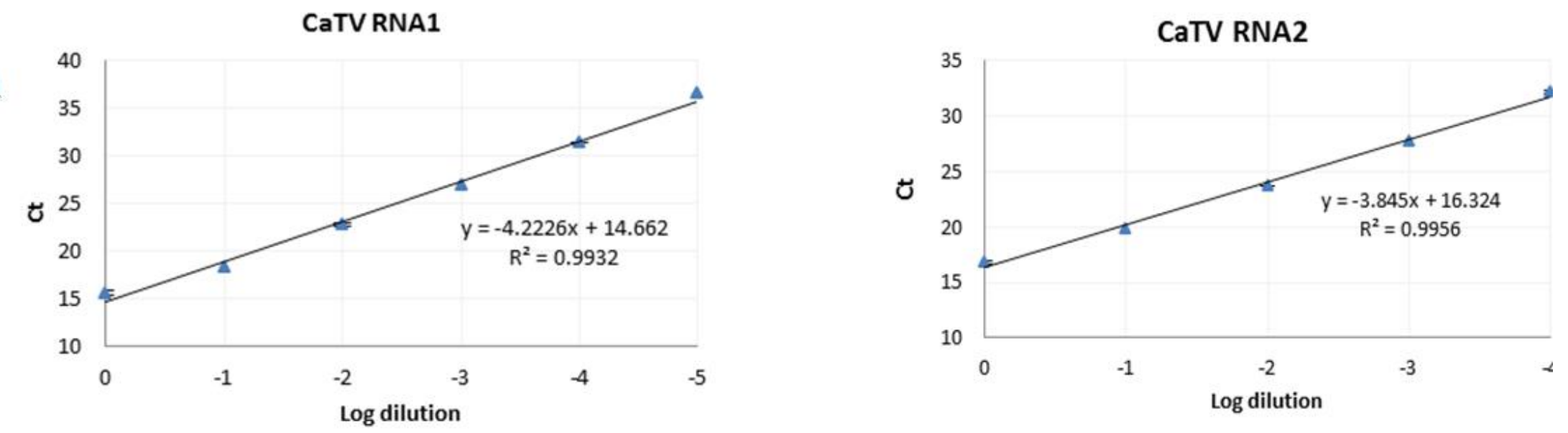

b
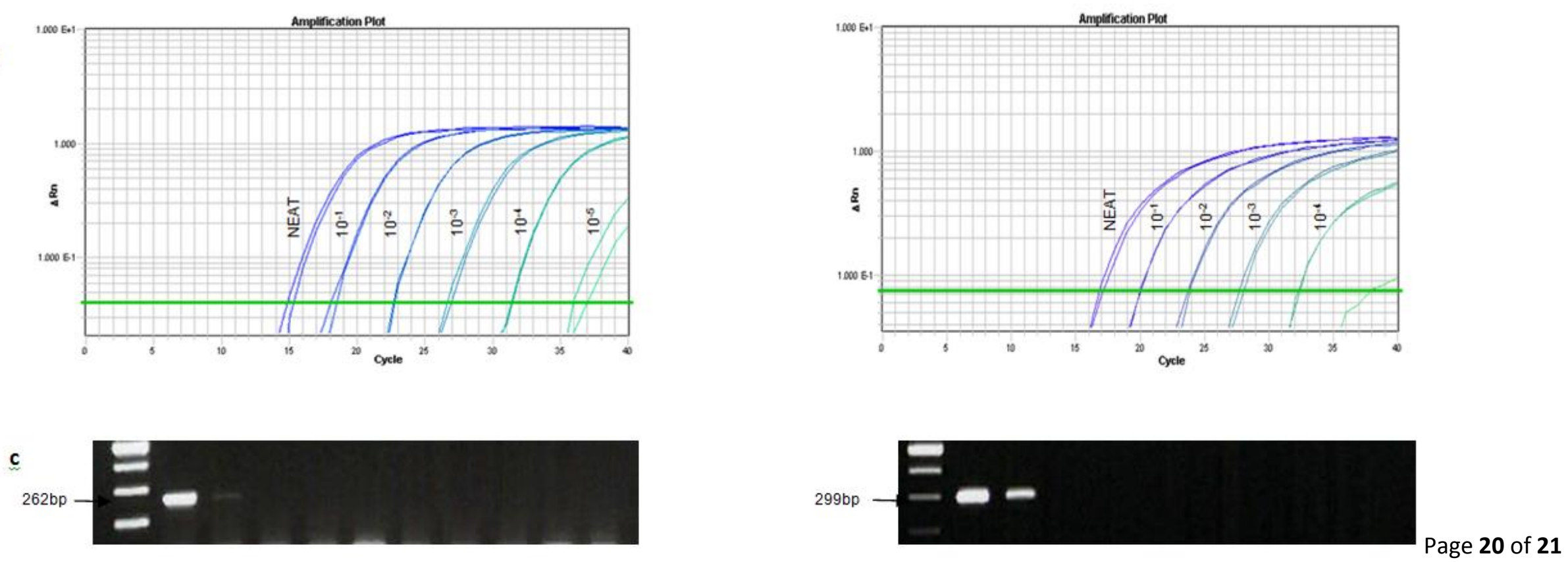


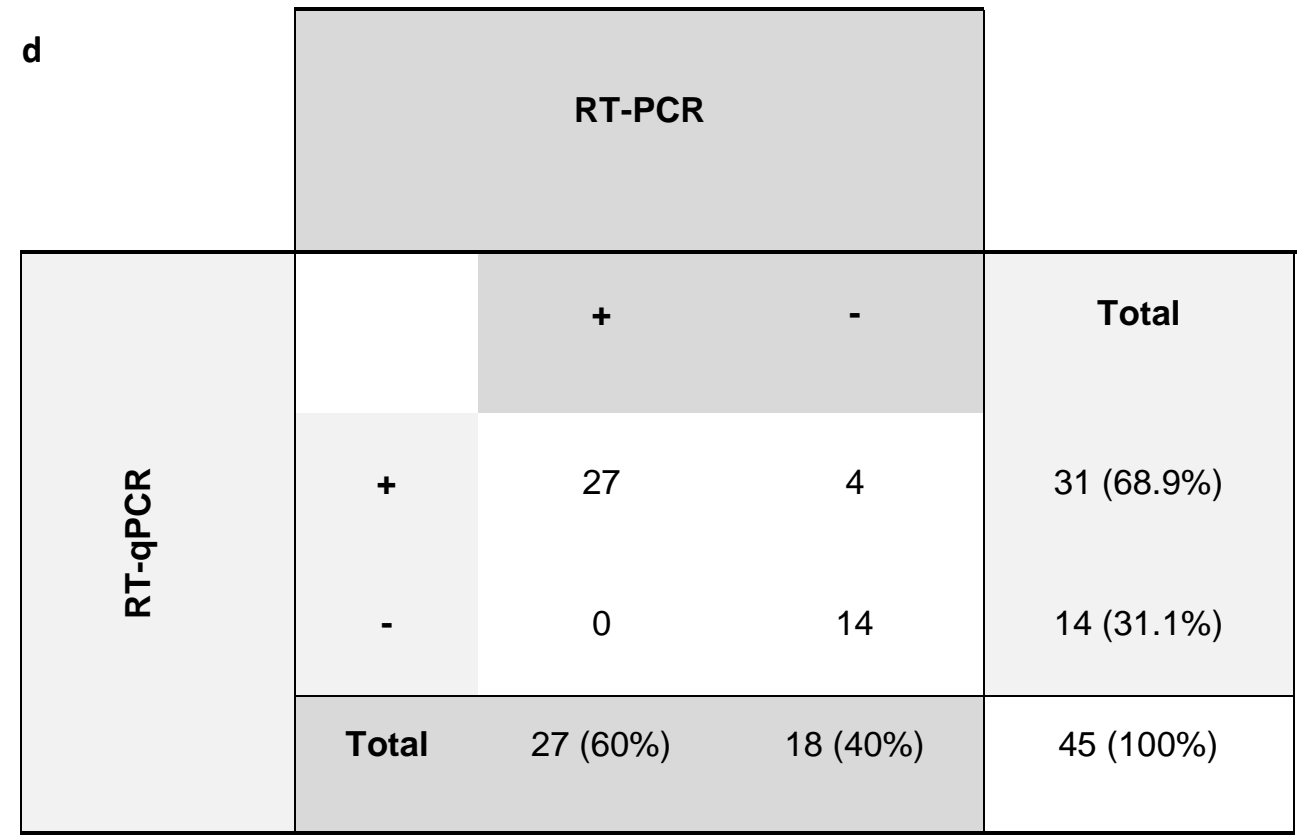

